\title{
РЕАКЦИЯ ПОЧВ И ДРУГИХ КОМПОНЕНТОВ ПРИРОДНОЙ СРЕДЫ НА КЛИМАТИЧЕСКИЕ ИЗМЕНЕНИЯ РАЗНОЙ ПЕРИОДИЧНОСТИ НА ЮГЕ СРЕДНЕРУССКОЙ ВОЗВЫШЕННОСТИ
}

\author{
(C) 2020 г. Ю. Г. Чендев ${ }^{a, *}$, А. А. Тишков ${ }^{a, b}$, И. Ю. Савин ${ }^{c}$, М. Г. Лебедева ${ }^{a}$, А. Б. Соловьев ${ }^{a}$ \\ ${ }^{a}$ Белгородский государственный национальный исследовательский университет, \\ Институт наук о Земле, Белгород, Россия \\ ${ }^{b}$ Институт географии РАН, Москва, Россия \\ ${ }^{c}$ Почвенный институт им. В.В. Докучаева, Москва, Россия \\ *e-mail: sciences@mail.ru \\ Поступила в редакцию 12.08 .2019 г. \\ После доработки 20.01.2020 г. \\ Принята к публикации 30.01.2020 г.
}

\begin{abstract}
Изучены ответные реакции компонентов природной среды на изменения климата разной периодичности на территории юга Среднерусской возвышенности. Современный межледниковый период в климатическом цикле эпох “ледниковье-межледниковье” рассмотрен как отражение голоценового саморазвития верхней гумусированной части профиля черноземов. Менее длительный период развития зональных почв лесостепи обосновывается для профилей автоморфных серых лесных почв региона, сформированных из черноземов в результате влияния позднеголоценового похолодания и обусловленного им надвигания лесов на степи. Сравниваются изменения компонентов природной среды (почв, грунтовых вод, болотных экосистем) в тепло-сухую и прохладновлажную фазы внутривековых изменений климата (циклов Брикнера), выявленных на основании анализа 127-летнего ряда метеорологических наблюдений на реперной станции Богородицкое-Фенино. Предложена концептуальная схема циклически возникающих явлений (повышения уровня грунтовых вод, подтопления, заболачивания, замочаривания и др.) в связи с внутривековой климатической изменчивостью. Важным методологическим принципом данной схемы выступают разновозрастность и различные характерные времена развития процессов и явлений, формирующих геосистемы изучаемой территории под влиянием изменений климата.
\end{abstract}

Ключевые слова: изменения климата, климатические циклы, Среднерусская возвышенность, лесостепь, почвы, эволюция и динамика почв, грунтовые воды

DOI: $10.31857 / \mathrm{S} 258755662003005 \mathrm{X}$

\section{ВВЕДЕНИЕ}

Цикличность изменения климата и обусловленных ею природных процессов раскрывает одну из важнейших закономерностей функционирования и развития географической оболочки ритмику ее процессов [10]. Природа этих явлений на протяжении всей истории Земли, включая историю биосферы, во многом обусловлена орбитально-космическими факторами вращения Земли и планет [12, 14 и др.]. Авторы обращают внимание на четкие связи между геодинамическими процессами (скорость вращения планеты и активность земных недр) и состоянием атмосферы (среднегодовая температура и концентрация углекислого газа) [6], что, в свою очередь, может свидетельствовать о существовании более сложных зависимостей изменения климата с космическими и земными геологическими процессами.
Механизмы этих сложных взаимодействий до конца не ясны и продолжают изучаться. Важность исследования климатических циклов связана с возможностями прогнозирования погодно-климатических и обусловленных ими других природных и социальных явлений. Их повторяемость в циклах развития географической оболочки является залогом успешности составления таких прогнозов, а существующие ошибки оценок зачастую связаны с недостаточностью накопленных эмпирических сведений об пространственно-временной изменчивости окружающей среды. Поэтому для решения проблемы изменений климата и предотвращения их нежелательных последствий для почв и экосистем, актуальным остается дальнейший сбор и анализ сведений об ответных реакциях компонентов окружающей среды на изменения климата разной периодичности, а также разработка на их основе принципов 
прогнозирования состояния экосистем на ближайшие десятилетия. Это важно для староосвоенных регионов с высоким природно-ресурсным потенциалом и экономическим развитием. Одним из таких регионов в России является аграрно освоенный юг Среднерусской возвышенности.

Цель исследования - анализ реакции почв, растительности, подземных вод, болотных экосистем на изменения климата разной периодичности на юге Среднерусской возвышенности, включая территории Белгородской, Воронежской и Липецкой областей.

\section{ОБЪЕКТЫ И МЕТОДЫ ИССЛЕДОВАНИЙ}

В данной работе одним из главных изучаемых компонентов являются почвы, характеристики которых претерпевали обратимые или необратимые изменения в ответ на вариации климата различной периодичности - от многотысячелетних до внутривековых циклов.

При рассмотрении климатогенной эволюции почв в голоцене были использованы результаты собственных полевых исследований и работы других авторов [3, 9, 28, 29]. В качестве примера длительной реакции компонентов ландшафта на изменения климата был выбран голоценовый тренд развития черноземов на дренированных водоразделах, эволюция которых изучалась на юге Среднерусской возвышенности. Примером развития почв широколиственных лесов в лесостепи, обусловленного изменениями климата в позднем голоцене, являются серые лесные почвы на водоразделе юга Липецкой области в бассейне р. Воронеж.

Главным методом изучения климатогенной эволюции почв является почвенно-археологический метод из группы методов почвенных хронорядов [4]. Он заключается в сравнении признаков почв, формирование которых было остановлено в разные исторические периоды в результате погребения под земляными насыпями археологических памятников (главным образом, курганами и оборонительными валами). Признаки разновозрастных погребенных почв сравниваются между собой, а также с признаками современных почв рядом с памятниками, формирование которых в естественном тренде продолжалось в течение всего голоцена. По выявляемым изменениям делается вывод о смене климатических обстановок, либо о поступательном развитии почвообразования в случае длительного существования неизменной комбинации факторов почвообразования.

Отклики компонентов окружающей среды на короткопериодические (внутривековые) вариации климата изучались на основе анализа 127 летнего ряда метеорологических показателей на реперной станции Богородицкое-Фенино. Основное внимание было уделено идентификации внутривековых квази-30-летних изменений климата в соответствии с циклами Брикнера, хотя, выявляются и другие, более короткопериодические вариации (в частности, 11-летний солнечной активности и 3-5-летний осадков). Эти циклы слишком коротки, чтобы необратимо повлиять на почвы и экосистемы, поэтому они в статье не рассматриваются. Сопряженно с указанным анализом была охарактеризована внутривековая динамика глубины грунтовых вод в Докучаевском колодце Каменной степи, изучены почвы переувлажненных земель (мочаров) на территории Яковлевского района Белгородской области, предложена гипотеза о формировании округлых контуров мочаров на склоновых землях, исследованы ареалы болотных экосистем на поверхности надпойменных террас р. Ворскла на территории Белгородской области и выявлено их изменение во времени.

Данные по метеорологическим рядам инструментальных наблюдений на реперной станции Богородицкое-Фенино Белгородской области, начиная с 1890-х годов, были предоставлены Белгородским центром по гидрометеорологии и мониторингу окружающей среды. Данные по глубине грунтовых вод в Докучаевском колодце Каменной степи получены на основе регулярных наблюдений, которые ведутся с 1892 г. [24].

При натурном исследовании почвы мочара и рядом расположенной фоновой почвы был использован метод морфологического анализа почвенного профиля и сравнительный метод исследования. Изменение во времени ареалов болотных экосистем изучалось с помощью материалов разновременных съемок земной поверхности, а именно, топографических планов 1955 г. (м-б 1 : 10000) и космического снимка 2014 г. высокого разрешения (в 1 пикселе 2 м), приведенного к картографической проекции.

\section{РЕЗУЛЬТАТЫ И ИХ ОБСУЖДЕНИЕ \\ Современный межледниковый тренд климатогенного развития почв}

Почвенный покров Земли выступает носителем разнообразных экологических функций, каждая из которых вносит свой вклад в сбалансированное развитие географической оболочки [5]. Неотъемлемым атрибутом длительных трендов развития экосистем, обусловленных долгопериодическими (многие тысячелетия) вариациями климата является процесс саморазвития почв, наблюдающийся в современный межледниковый период. Голоцен многими исследователями рассматривается как длительная и относительно однородная в природно-климатическом отношении эпоха, имеющая существенные отличия от предыдущей ледниковой эпохи. На большом количестве при- 
меров в разных регионах Земли было доказано, что при переходе от плейстоцена к голоцену происходили грандиозные преобразования природы всей нашей планеты. "Главной причиной этих преобразований, равно как и последующего, более плавного развития природных процессов послужили глобальные изменения климата, особенно резко проявившиеся на рубеже плейстоцена и голоцена" [11, с. 5]. Согласно [31], а затем на основании результатов исследований других авторов $[1,4,23]$ доказано, что почвы при относительно стабильной комбинации факторов среды подчиняются экспоненциальному закону развития с замедлением во времени темпов почвообразования. Для юга Среднерусской возвышенности и соседних территорий примером такого саморазвития в голоценовом тренде выступает изменение во времени мощности гумусированной части профиля черноземов. Черноземы, формирующиеся на плакорах, были выбраны с учетом того, что по данным почвам имеется максимальное количество результатов исследований, обобщенных в единый длительный хроноряд изменения свойств [27]. Представленный на рис. 1 хроноряд голоценового развития мощности гумусированной части черноземов на ровных водоразделах доказывает экспоненциальный характер изменения во времени процесса, а также то, что экспоненциальное развитие нарушалось эпизодическими изменениями климата внутри голоцена (см. рис. 1). Реакция снижения мощности гумусированной части профиля черноземов в ответ на эпизодически происходившие аридизации климата требует отдельного рассмотрения и в задачу настоящей статьи не входит. Отсчет прироста гумусового профиля черноземов на схеме рис. 1 был взят с начала голоцена (10 300 л. н.) как нуль-момент почвообразования. Ранее могли проявляться литогенные факторы, связанные с процессами вытаивания вечномерзлых пород и перемешивания почвенно-грунтовой толщи, что препятствовало поступательному почвообразовательному процессу.

Кроме черноземов, в лесостепи юга Среднерусской возвышенности также широко распространен зональный почвенный тип - серые лесные почвы, сформированные под пологом широколиственных лесов. По совокупности полученных нами и другими данных $[1,25,26]$ возраст естественных ареалов широколиственных лесов региона и сформированных под ними серых лесных почв - позднеголоценовый, а основной этап трансформации здесь черноземов в серые лесные почвы длится на протяжении последних 16001800 лет [30]. Надвигание лесов на степи и эволюционная трансформация черноземов в серые лесные почвы были обусловлены похолоданием и увлажнением климата в конце суббореального и в субатлантическом периоде голоцена. В качестве

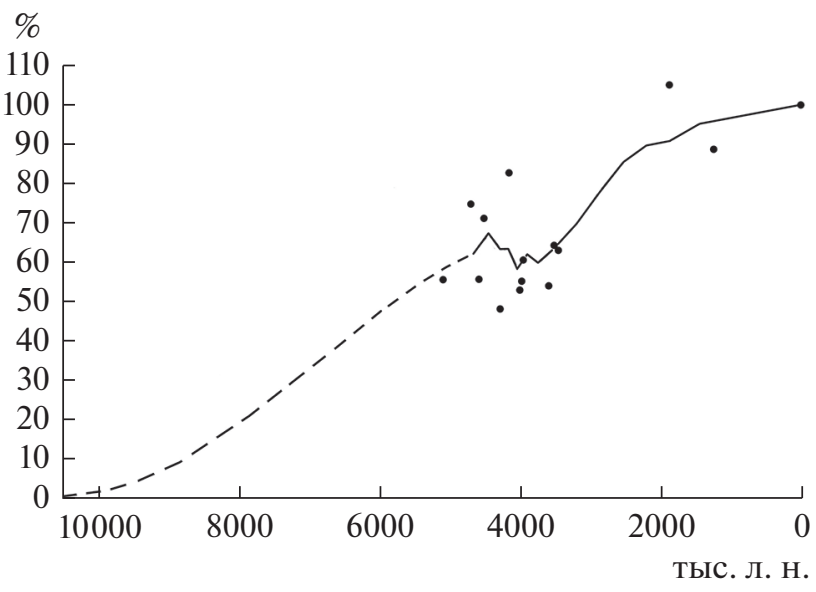

Рис. 1. Изменение во времени мощности гумусированной части профиля (сумма горизонтов A1 и А1B) черноземов в центре Восточной Европы, \% от современных значений. Пунктирная линия - реконструкция до 5000 лет назад, сплошная линия - выровненный ряд на основании сглаживания по пяти соседним значениям показателя. Составлено Ю.Г. Чендевым [27] с учетом обобщения результатов собственных исследований, а также исследований А.Л. Александровского, И.В. Иванова, В.П. Золотуна и др. авторов. Время приводится в некалиброванном летоисчислении.

примера саморазвития серых лесных почв из профиля черноземов нами приводится схема хроноряда среднесуглинистых почв (погребенных под разновозрастными земляными валами и фоновой) на водоразделе городища Подгорное Липецкой области (рис. 2).

Таким образом, голоценовое почвообразование в голоценовом климатическом тренде на территории юга Среднерусской возвышенности сформировало разновозрастные ареалы зональных почв региона: черноземы формируются с начала голоцена, а серые лесные почвы имеют меньший период саморазвития и произошли от черноземов в результате климатически обусловленного надвигания лесов на степи в позднем голоцене.

\section{Внутривековые изменения климата и реакция на них компонентов окружающей среды}

Одним из первых отечественных исследователей, обративших внимание на существенную роль коротких внутривековых изменений климата, был Л.С. Берг. Им охарактеризована климатическая смена в начале XX в., когда в результате теплых зим изменились жизненные циклы и ареалы обитания многих сухопутных и водных организмов Европы [2]. Л.В. Клименко [13] произвел анализ сезонного хода температур по данным сети метеорологических станций в южной половине Восточно-Европейской равнины $\left(45^{\circ}-55^{\circ}\right.$ с.ш. и $30^{\circ}-50^{\circ}$ в.д.) за период с 1891 по 1990 г. Колеба- 


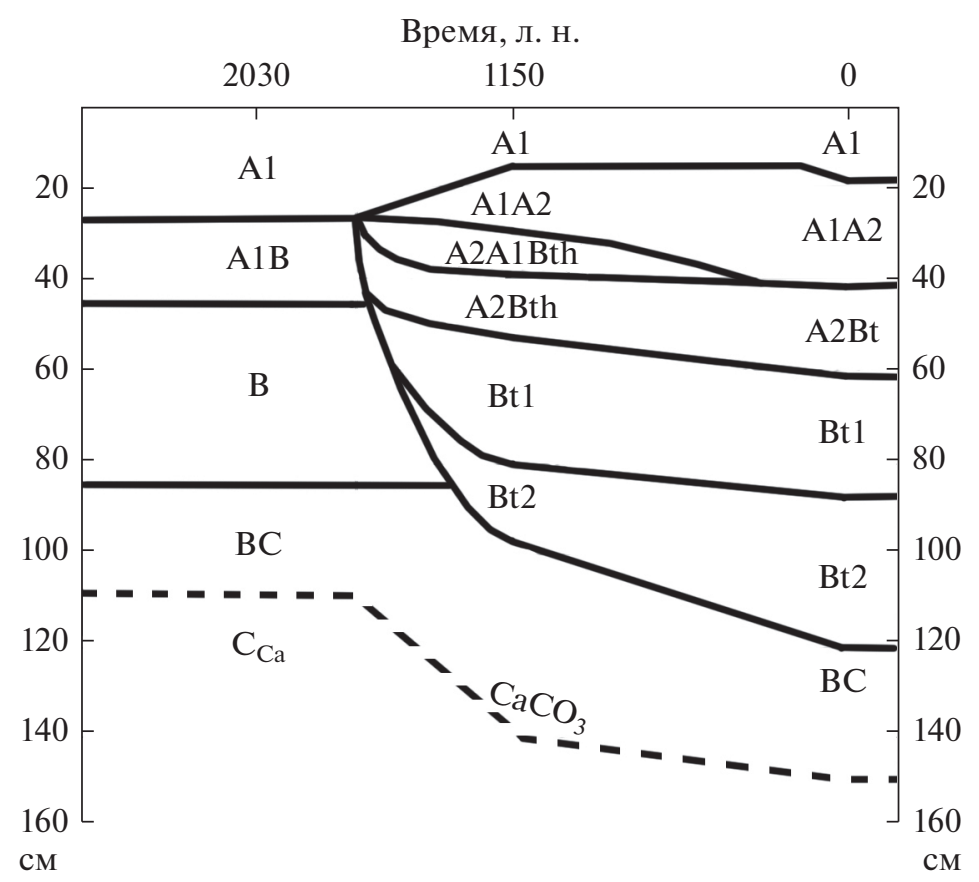

Рис. 2. Хроноряд почв, отражающий эволюцию среднесуглинистых черноземов в серые лесные почвы (городище Подгорное в 150 км от границы со степью). Составлено по данным из [30].

ния температуры летних и зимних сезонов в течение 100 лет показали наличие двух крупных волн похолоданий в летнее время (1920-1930-е годы и 1970-1980-е годы) и синхронных с ними волн потеплений в зимнее время. Л.В. Клименко [13] объяснил это тем, что одни и те же атмосферные процессы в разных сезонах могут приводить к различному климатическому эффекту. С начала 1970-х годов резко возросла циклоническая деятельность, и в холодный период стали чаще возникать положительные аномалии температуры, а в теплые месяцы - отрицательные с осадками [13].

На рис. 3 приведены временные ряды изменения температур и осадков вегетационного периода на реперной метеостанции Богородицкое-Фенино (Губкинский район Белгородской области) - наиболее длительные за весь период инструментальных наблюдений на территории Центрального Черноземья. Период май-сентябрь был выбран с учетом того, что он характеризует комплексный климатический показатель - гидротермический коэффициент, определяющий особенности продукционного процесса в экосистемах и биологического круговорота. Полиномиальное сглаживание хода рассматриваемых показателей (см. рис. 3в) отражает их противоположно направленные изменения во времени, что в целом согласуется с выявленными Л.В. Клименко [13] сменами фаз циклогенеза и антициклогенеза. При этом отмечается запаздывание на 5-10 лет периодов формирования максимумов выпадения осадков по отношению к периодам образования минимальных температур (см. рис. 3в). Это позволяет идентифицировать динамические изменения климата с наличием его внутривековых фаз: фазы понижения температур и роста количества осадков в 1890-1912 гг., фазы роста температур и понижения количества осадков в 1913-1938 гг., фазы понижения температур и роста количества осадков в 1939-1986 гг. и, наконец, современной фазы роста температур и снижения количества осадков в 1987-2017 гг. Согласно указанному разделению (по парам - аналогам климатических фаз), средняя длительность внутривековых понижений температур и роста количества осадков в течение вегетационного периода за прошедшие 127 лет составила 35.5 лет, а фаз роста температур и понижения количества осадков - 28.5 лет. Таким образом, выявляются квази-30-летние фазы внутривековых изменений, отражающие циклы Брикнера.

В Каменной степи режимные наблюдения за уровнем грунтовых вод в Докучаевском колодце проводятся с 1892 г. Их результаты представлены на рис. 4. Как видно, колебания уровня в колодце подчиняются той же ритмике, которая установлена для внутривековых изменений климата (см. рис. 3): выявляются две волны повышения уровня грунтовых вод, соответствующие периодам роста количества атмосферных осадков (при циклогенезе) и разделяющая их волна низкого стояния грунтовых вод, отражающая период пониженного увлажнения климата (при антициклональном режиме формирования погодных процессов). Начиная с 2000 г. наблюдается устойчивая тенденция 


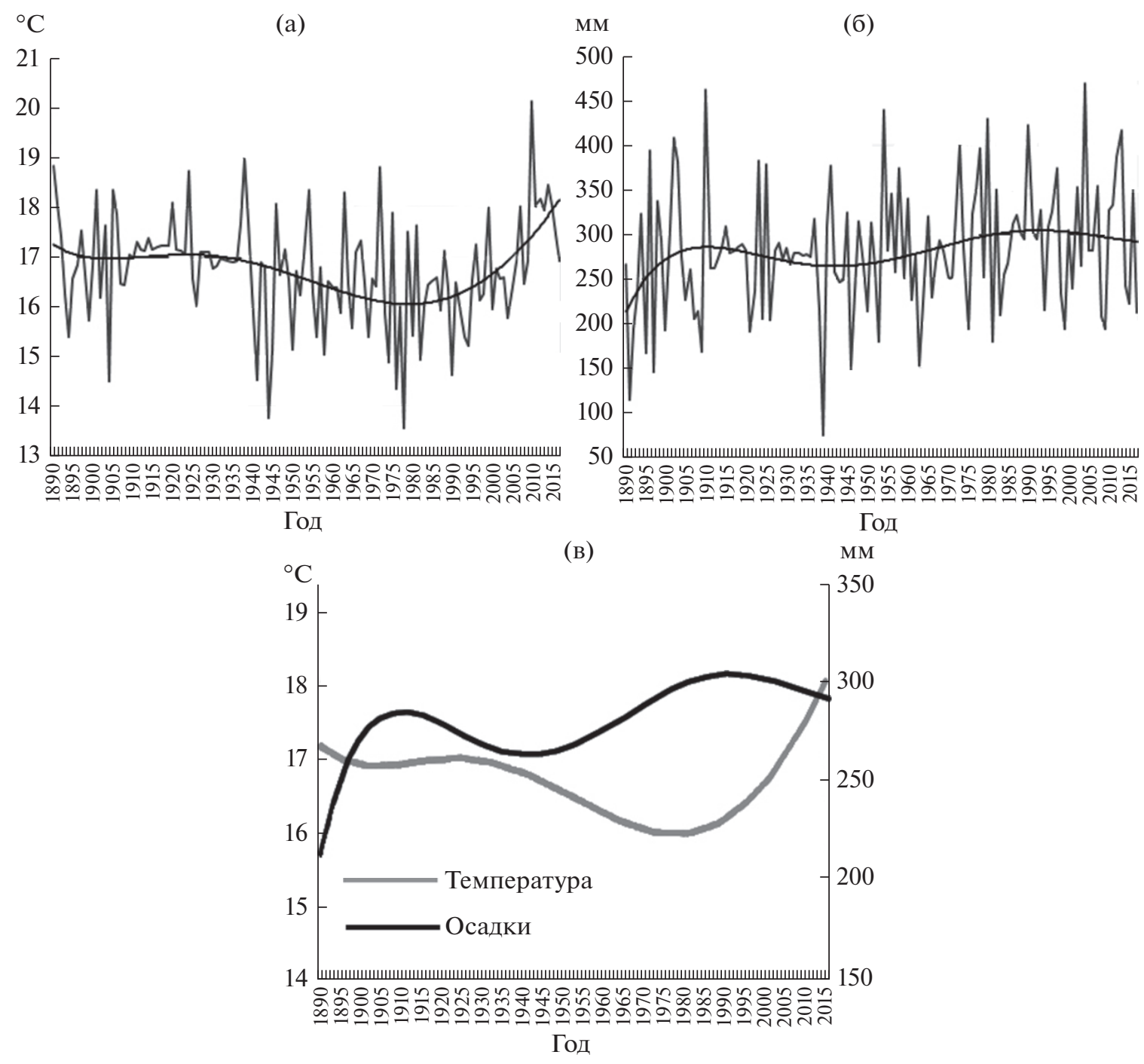

Рис. 3. Ход метеорологических показателей на станции Богородицкое-Фенино: a - средние температуры вегетационного периода (май-сентабрь) с полиномом 6 степени, 6 - средние количества атмосферных осадков вегетационного периода с полиномом 6 степени, в - полиномиальное сглаживание хода температур и атмосферных осадков вегетационного периода (полиномы 6 степени).

низкого стояния грунтовых вод, соответствующая современному тренду антициклональной циркуляции атмосферы (см. рис. 4).

Примечательно, что первая волна повышения уровня грунтовых вод в конце XIX-начале XX в. была менее выразительной по сравнению с волной конца XX-начала XXI в. - в соответствии с аналогичными амплитудами в динамике метеорологических элементов, выявляемой по наблюдениям на станции Богородицкое-Фенино (см. рис. Зв).

Весьма вероятной была инерционность (запаздывание на 3-5 лет) достижения минимумов и максимумов глубин грунтовых вод (см. рис. 4) по отношению к формированию обратных им максимумов и минимумов выпадения атмосферных осадков в теплую половину года (см. рис. 3в).
В последний из внутривековых периодов повышенного увлажнения XX в. происходило закономерное изменение не только уровня грунтовых вод, но также других компонентов природной среды - почв и болот.

По результатам исследования П.Н. Соловьева [22], режимные наблюдения за влажностью целинного чернозема в Центрально-Черноземном заповеднике в период с 1946 по 1984 г. выявили смену фаз климата в 1957 г. Однако новая фаза запаздывала во времени и наступила только в середине 1960-х годов, когда стабилизировались почвенно-гидрологическая и межгодовая изменчивость влажности почвы. Согласно мнению автора, смена фаз климата происходит в соответствии с циклом Брикнера через каждые 30-36 лет, поэто- 


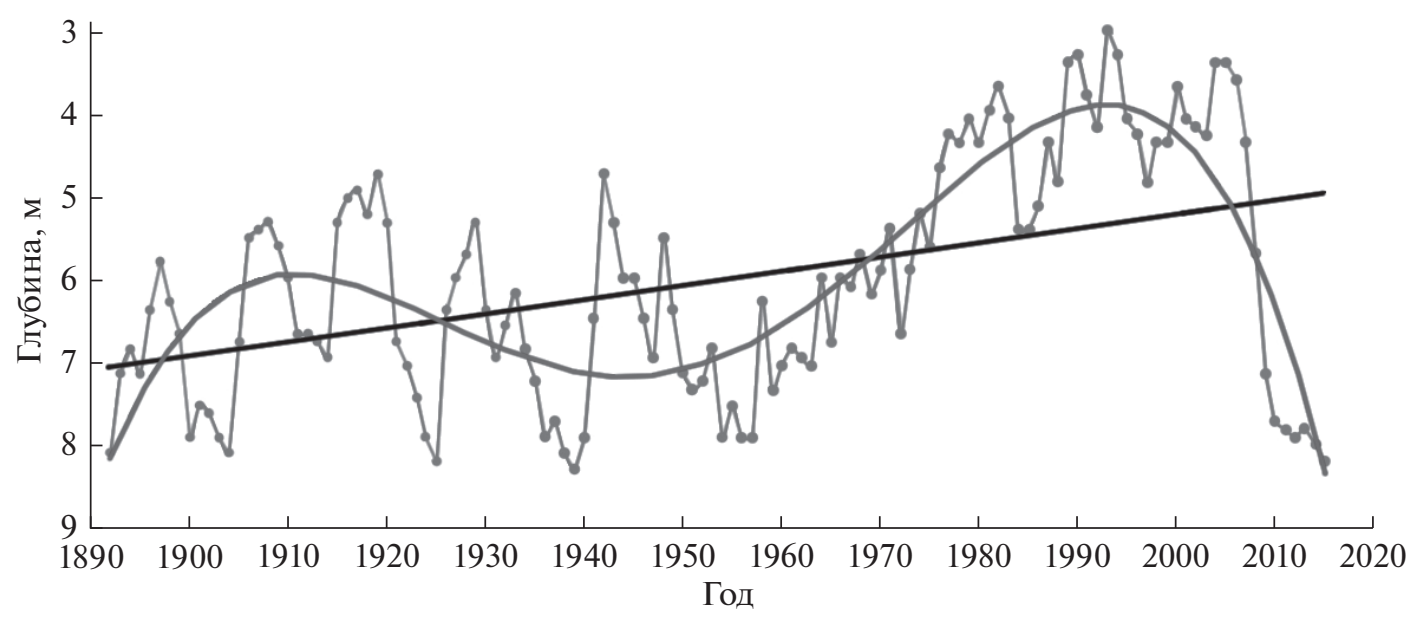

Рис. 4. Динамика уровня грунтовых вод в Докучаевском колодце: фактический ряд изменений, линейный и полиномиальный (полином 6 степени) тренды. Составлено по [24].

му спрогнозированная им неизменность режима влажности чернозема до 2000 г. вполне оправдалась [22].

При сравнении аэрофотоснимков периодов 1961-1965 и 1984-1987 гг., на основании которых производилось дешифрование почвенного покрова лесостепи Центрально-Черноземного района, выяснилось, что структура почвенного покрова меняется в ходе обусловленного естественными причинами усиления выщелоченности черноземно-луговых почв балочных систем. На это указывал, в частности, наблюдавшийся процесс зарастания днищ и склонов балок кустарниковой и лесной растительностью [21].

Многие авторы отмечали, что, начиная с 1965 г., в черноземной зоне Восточно-Европейской равнины широкое распространение получили переувлажненные почвы. В лесостепи и северной степи наблюдалось олуговение автоморфных почв на 25-45\% их ареала. Стали возникать ареалы подтопленных земель - мочары. Их количество в гумидный климатический цикл увеличилось в пять-десять раз по сравнению с предшествующим, более аридным климатическим эпизодом.

Отмечается пульсационный характер изменения площади мочаров во влажные и сухие периоды. Площади, занятые мочарами, возрастали и в предшествовавший современному, цикл увлажнения климата в 1920-1930-х годах. Наряду с их возникновением, на пониженных участках складывались благоприятные условия для подъема карбонатов, что привело к увеличению в этот период площадей карбонатных черноземов [18-20].

За более чем 30-летний период наблюдений (с 1985 г.) нами отмечается появление переувлажненных почв на покатых склонах водоразделов и покато-крутых склонах балок юга Среднерусской возвышенности. Их количество возрастало вплоть до конца 1990-х годов. Позднее наметилась тенденция сокращения ареалов данных почв. Однако и в настоящее время пятна переувлажненных почв на склонах во многих местах региона продолжают маркироваться гидрофитной растительностью, в составе которой можно встретить тростник, вейники, разные виды осок (рис. 5).

В соответствии с предложенной типизацией, мочары бывают климатогенными (выявляемые в микродепрессиях уплощенных водоразделов со слабоводопроницаемыми породами) и литогенными (обусловленными наличием водоупоров в пределах склона) [8]. На юге Среднерусской возвышенности (Белгородская область), широкое распространение в недавно завершившийся внутривековой период повышенного увлажнения (см. рис. 3в), по нашему мнению, получили именно литогенные мочары. Один из примеров таких почв был изучен на балочном склоне южной экспозиции в Ивнянском районе Белгородской области близ пос. Покровский (рис. 6).

Почвообразующими породами являются палевые карбонатные лессовидные суглинки. В месте формирования мочара почва была идентифицирована как черноземно-луговая грунтово глеевая со следующим строением профиля: А1-A1B-

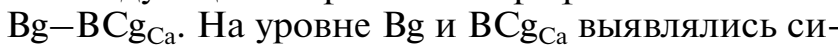
зоватые и рыже-сизые зоны грунтового оглеения, а в горизонте $\mathrm{BCg}_{\mathrm{Ca}}$ карбонаты были представлены скоплениями белоглазки и журавчиков гидрогенного генезиса. Рядом расположенная, но за пределами мочара, фоновая почва была идентифицирована как чернозем типичный без признаков оглеения с характерными для данного подтипа формами карбонатов - псевдомицелием и очаговыми пятнами плесени.

Одной из выявленных нами закономерностей выступает более высокая встречаемость пятен ли- 


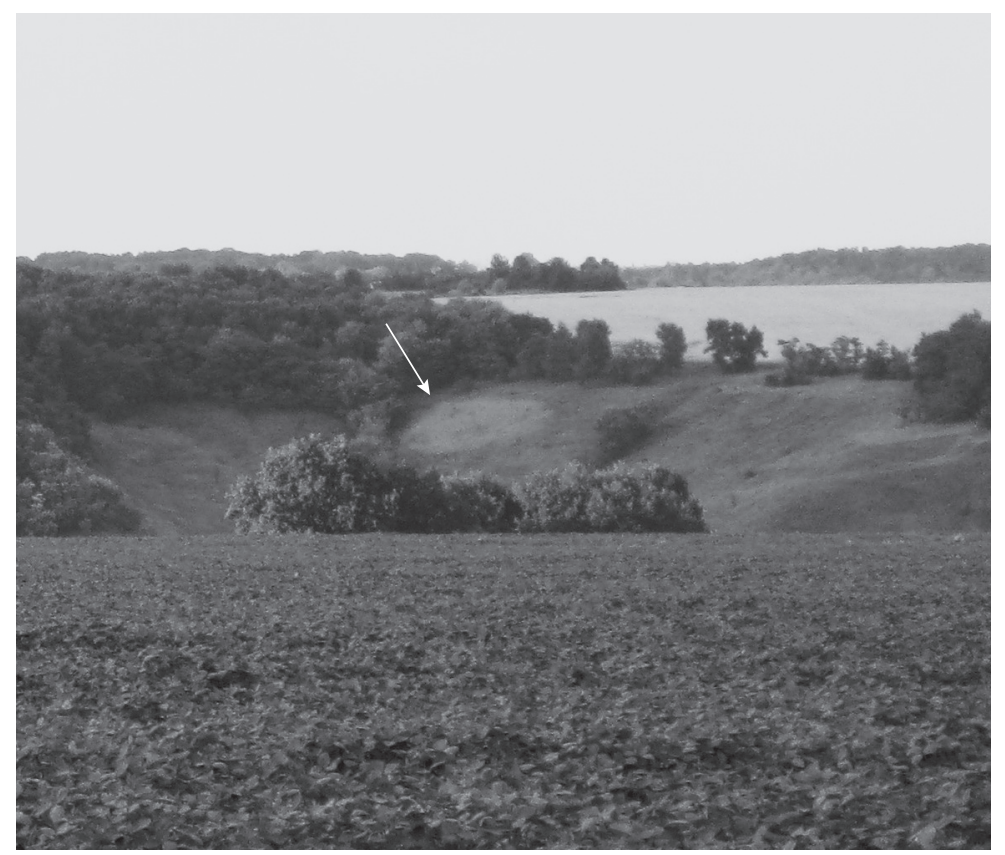

Рис. 5. Пятно мочара на склоне балки, маркируемое светлым тоном осоковой растительности.

тогенных мочаров на склонах южных экспозиций по сравнению с другими склонами, а также овальный вид самих мочаров, ширина которых варьирует от нескольких до 20-30 м. Причины овальной формы литогенных мочаров, насколько нам известно, в литературе не обсуждались. Нами предлагается палеогеоморфологическое объяснение этому феномену - пятна мочаров маркируют собой выклинивающиеся к поверхности современных склонов погребенные палеобалки и палеоложбины, которые заполнены относительно рыхлыми позднеплейстоценовыми отложениями (по сравнению с выстилающими поверхность погребенными почвами), включающими переотложенные лессовидные суглинки. В периоды повышенного увлажнения климата (прохладно-влажные фазы внутривековых гелиоклиматических циклов) геологические породы, которыми заполнены палеобалки и палеоложбины, словно губка, насыщаются почвенными водами, после чего эти воды широким фронтом начинают перемещаться вниз, и выходят на поверхность в местах выклинивания к поверхности современных склонов указанных выше палеобалок или палеоложбин. Схему образования мочаров на склоновом типе местности демонстрирует рис. 7 .

Выдвинутая гипотеза находит подтверждение в результатах сравнительно недавно проведенных палеогеографических исследований. На территории центра и юга Восточно-Европейской равнины в пределах склонового типа местности было выявлено широкое распространение древнего ложбинного рельефа. Согласно реконструкциям
Е.А. Еременко и А.В. Панина [7] поверхность склонов речных долин и балок в начале эпохи валдайского похолодания была в большей степени осложнена неровностями в форме ложбин и лощин, чем в настоящее время. Исследователи предполагают, что формирование древнего ложбинного рельефа происходило в эпоху московского позднеледниковья (перед микулинским межледниковьем), когда глубина и густота эрозионного расчленения повсеместно превышали современные. В течение поздневалдайского криохрона, в эпоху интенсивного лессонакопления, эти линейные депрессии рельефа оказались заполненными склоновыми отложениями [7], то есть произошло нивелирование палеорельефа позднеплейстоценовым осадконакоплением.

На основании этой реконструкции, преобладание мочаров на склонах южных экспозиций в современном ландшафте изучаемой территории вполне обосновано с учетом большей встречаемости здесь древних палеоложбин, которые, в свою очередь, формировались при более интенсивном проявлении на инсолируемых склонах процессов линейной эрозии. Кроме того, строение склонов южной и северной экспозиции на данной территории разное. На северной - чехол четвертичных отложений более мощный и нет выклинивания на склонах более древних пород, являющихся водоупорами, а на южном склоне часто выклиниваются все породы, начиная от мела и залегающих выше него палеогеновых и неогеновых отложений, на которых и лежат покровные лёссовидные суглинки. 
(a)
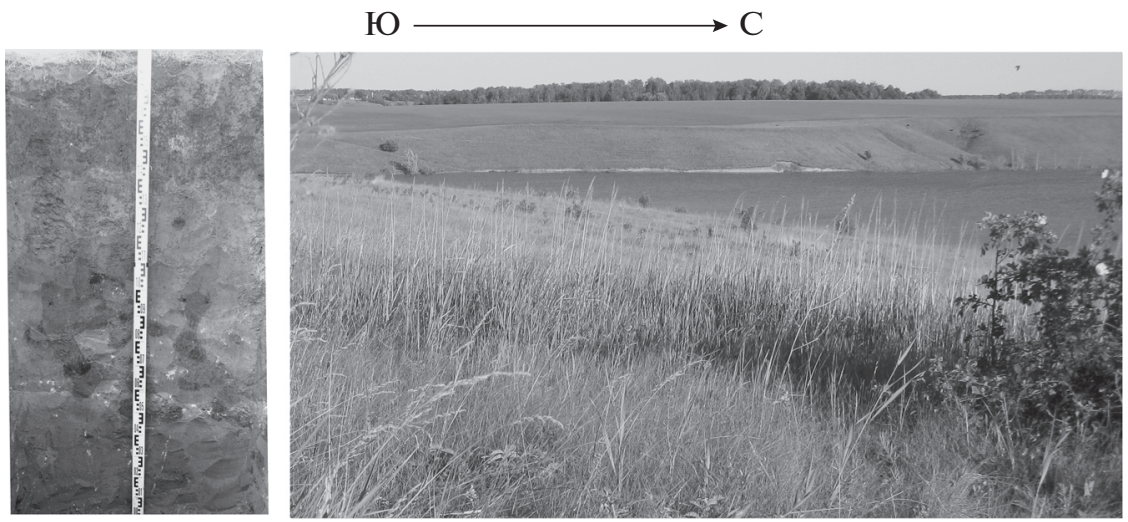

(б)
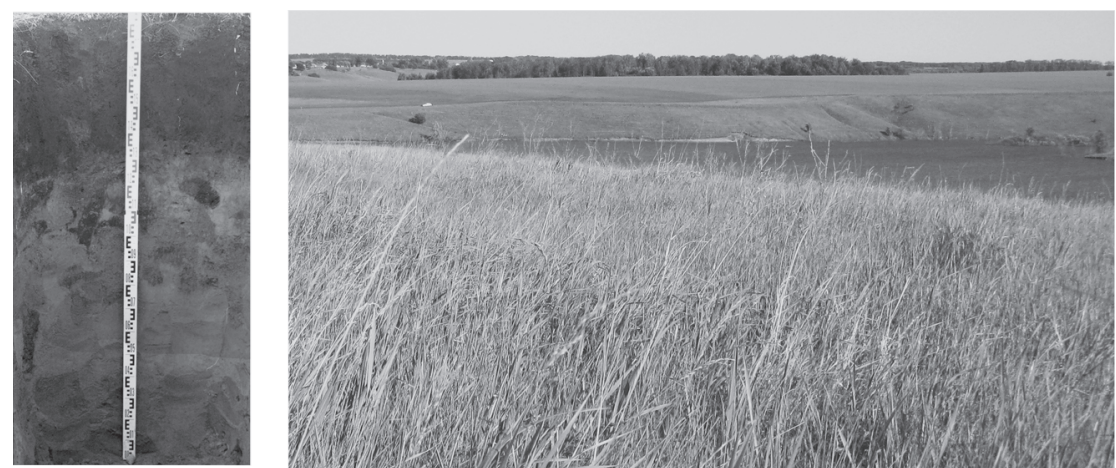

Рис. 6. Профиль черноземно-луговой грунтово-глеевой почвы в месте формирования мочара (осоковая и вейниковая растительность, а также куст шиповника маркируют это место (а) и профиль фонового чернозема типичного на том же элементе склона балки за пределами мочара под типичным луговым разнотравьем (б).

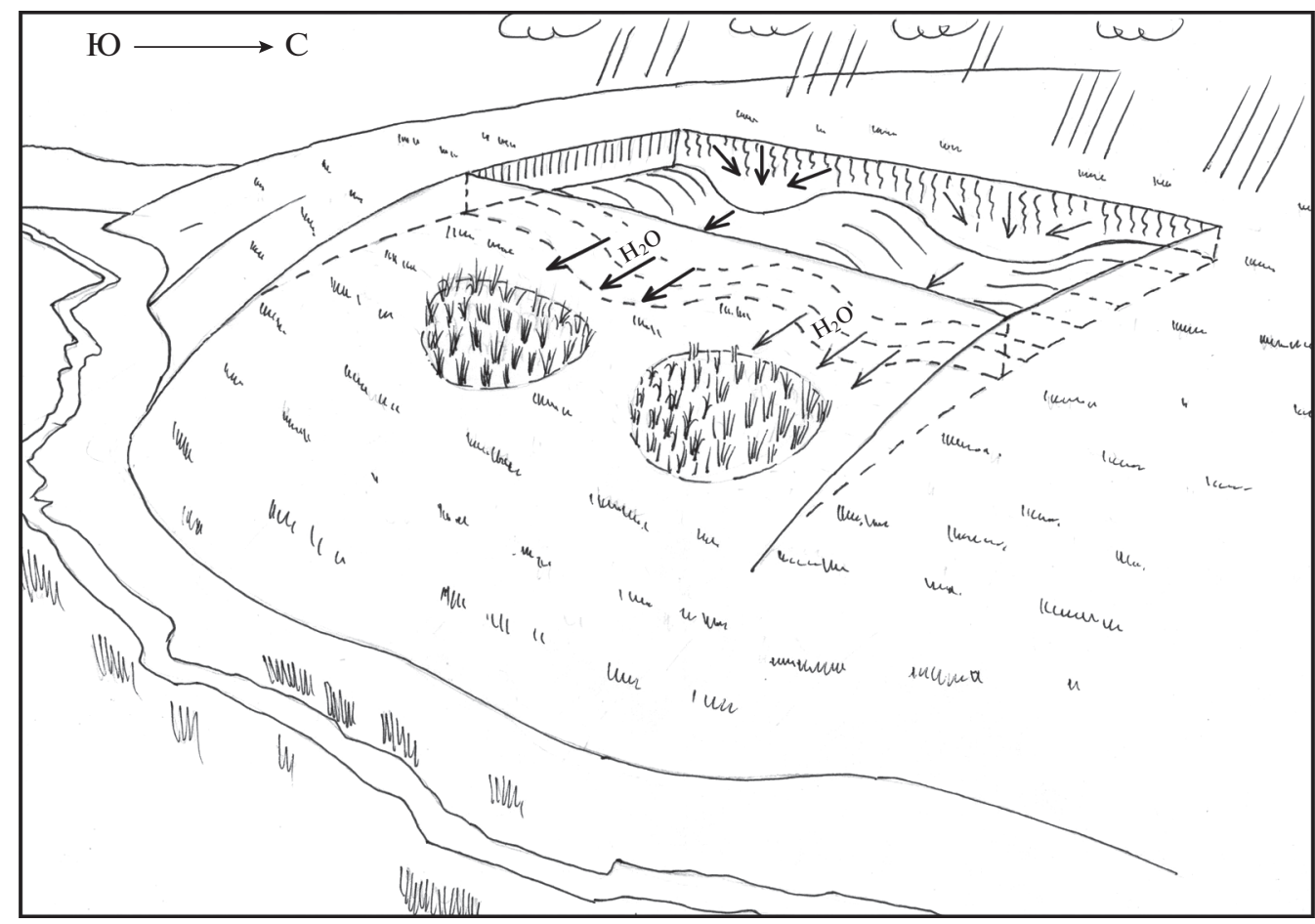

Рис. 7. Гипотетическая схема формирования мочаров на склонах долинно-балочной сети юга Среднерусской возвышенности в местах выклинивания погребенных палеоложбин, заполненных относительно рыхлыми и более мощными по сравнению с окружающими участками позднеплейстоценовыми отложениями. 
Кроме закономерных колебаний уровня грунтовых вод и цикличных процессов образования мочаров нами наблюдалась динамика заболачивания, которая также была генетически связана с внутривековыми изменениями климата.

В качестве модельного полигона были взяты боровые надпойменные террасы р. Ворскла левобережной части ее долины в Белгородской области, наблюдения за которыми нами проводятся на протяжении более 40 лет. На участках наблюдения поверхность первой и второй надпойменных террас занята хвойно-широколиственными лесами с преобладанием дуба, березы, сосны. Поверхность террас осложнена обширными депрессиями карстового или эолового происхождения диаметром от 50 до 300 м и глубиной $1.5-3$ м. До начала 1980-х годов большинство депрессий было занято чистыми березняками, которые формировались в мезоморфных условиях с относительно неглубоким залеганием грунтовых вод. За период с середины 1980-х по начало 1990-х годов (в связи “брикнеровским” циклом увлажнения климата), происходило интенсивное заболачивание депрессий. Почвы депрессий из перегнойно-глееватых за короткий срок эволюционировали в торфянисто-болотные и субаквальные. Березняки деградировали; остатки сгнивших стволов еще в конце 1990-х годов можно было наблюдать в центральных частях низинных болот, которые на периферии покрылись зарослями рогоза и тростника (рис. 8).

С 2010-х годов на изучаемой территории начала формироваться устойчивая тенденция осушения болот, причиной которого следует считать климатически обусловленное понижение уровня грунтовых вод (в соответствии с выявленной закономерностью их внутривековой динамики, см. рис. 4). На периферии осушающихся болот стали появляться молодые ростки и деревья березы, которые позволяют предполагать развитие в текущую тепло-сухую фазу климата ориентировочной продолжительностью в 30 лет новых березняков в ранее заболоченных депрессиях. Циклически меняющиеся почвы депрессий требуют более внимательного исследования, отдельного отражения на картах и введения в почвенную классификацию.

Наглядным доказательством развития в конце $\mathrm{XX}$ в. болотного процесса в депрессиях надпойменных террас р. Ворскла выступает сравнение ареалов болот по топографической карте середины XX в. и современному спутниковому снимку (рис. 9).

Представленные примеры не исчерпывают всего многообразия влияния внутривековой климатической цикличности на окружающую среду изучаемой территории. Так, в Белгороде в 19601970-х годах популярным было катание горожан на лыжах в выходные дни на крутых склонах

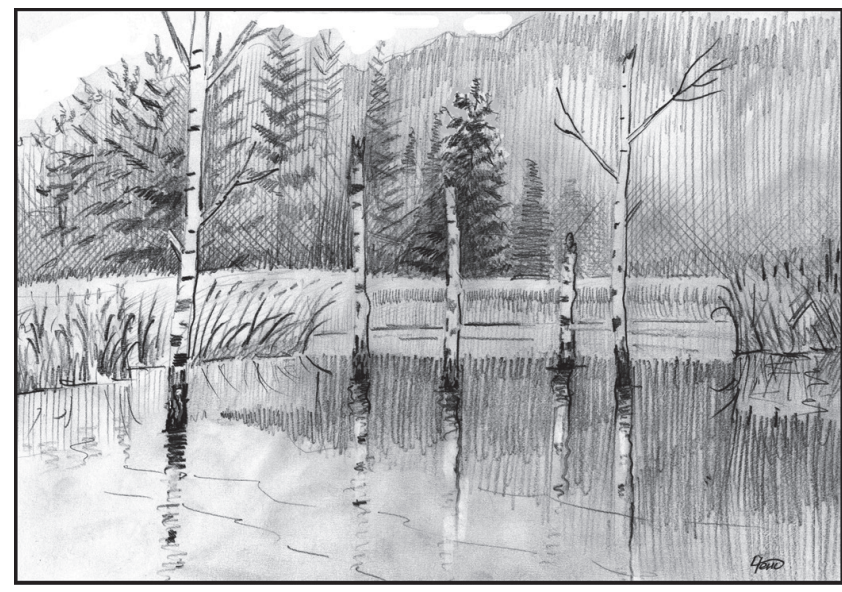

Рис. 8. Характерный вид депрессии на поверхности надпойменной террасы р. Ворсклы, заболоченной в прохладно-влажную фазу климата 1980-1990-х годов, с остатками сгнивших стволов берез на месте существовавшего ранее (в тепло-сухую фазу климата) березняка (рис. Ю.Г. Чендева в 1996 г.).

крупной балки под названием “Меловые горы” на северо-восточной окраине города. В это же время традиционными были посещения катка на центральном стадионе города. С конца 1980-х и до 2010 г. данные развлечения прекратили существование из-за участившихся в зимнее время оттепелей. Опрос молодежи г. Белгорода, родившейся в начале 1990-х годов, показал, что многие из них даже не подозревали о том, что не так давно существовала многолетняя традиция массовых катаний на коньках и лыжах в зимнее время. Данный аспект интересен с точки зрения изучения изменчивости во времени социальных приоритетов, традиций, моды. Как видно, в ряде случаев изменения климата могут существенно влиять на указанные явления. С 2010-х годов (с наступлением внутривековой климатической фазы антициклогенеза) катание на лыжах и коньках в городе и его окрестностях постепенно стали возобновляться.

Имеются основания полагать, что внутривековая климатическая цикличность является регулярным явлением, которая длительное время инициирует короткопериодическую (на протяжении первых десятилетий) ритмику географических процессов. В работе [31] имеется указание на идентификацию циклов Брикнера средней длительностью 34 года во временных рядах радиальных приростов секвойи гигантской с возрастом отдельных экземпляров до 3000 лет.

При анализе рукописей позднего средневековья, характеризующих события в лесостепи Среднерусской возвышенности в середине XVII в., были обнаружены свидетельства смен гидрологического режима рек, уровней грунтовых вод, атмосферных процессов в интервале времени с 1648 

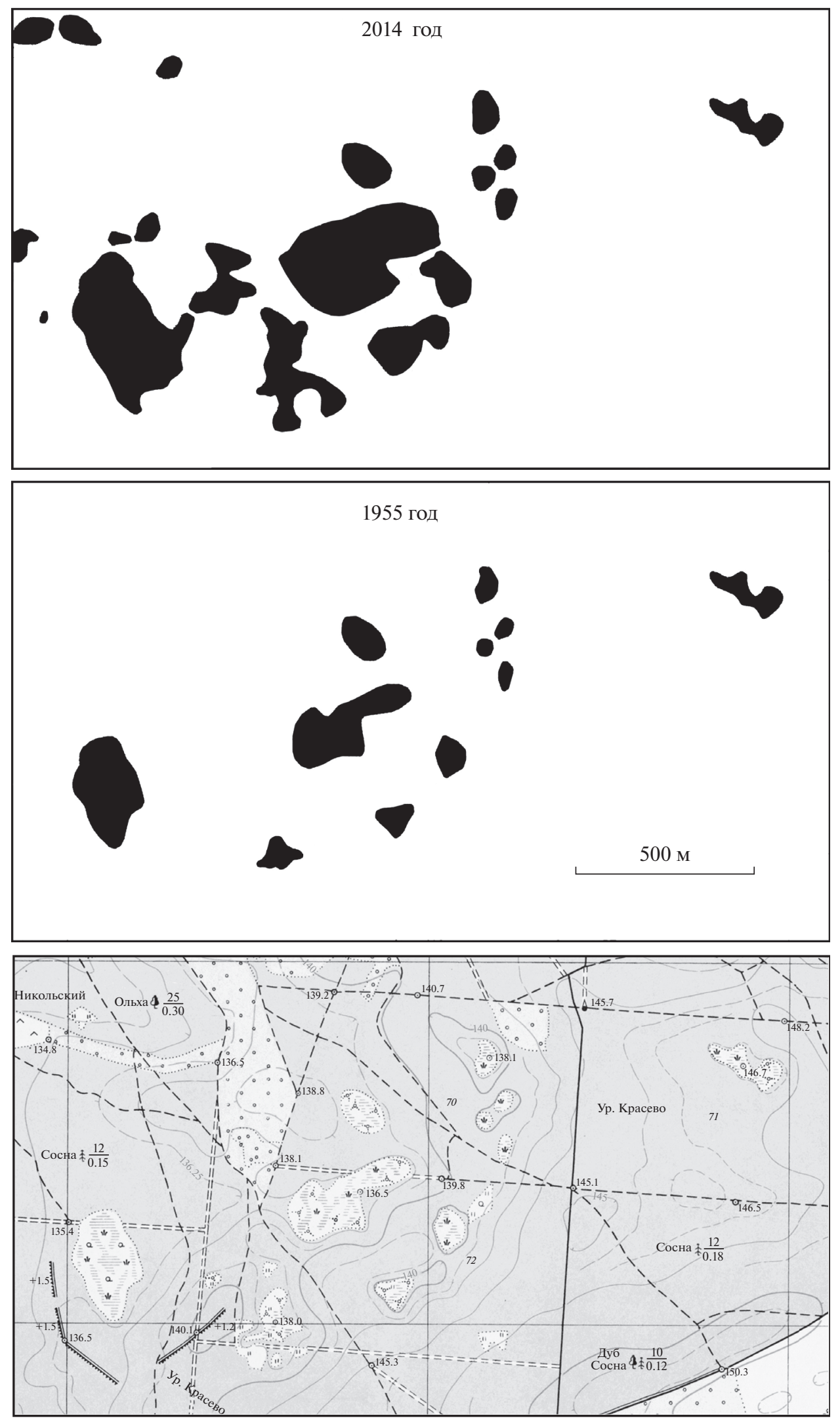

Рис. 9. Изменение площадей болот на поверхности надпойменной террасы р. Ворсклы за два сравниваемых периода: 1955 г. - данные топографической карты масштаба $1: 10$ 000; 2014 г. - данные космического снимка в ортогональной проекции (разрешение: 1 пиксель - 2 м). Внизу - участок изучаемой территории на топоплане 1955 г. 
по 1666 гг. Так, повышение уровня грунтовых вод и начавшееся заболачивание в Белгородской крепости, построенной тремя десятилетиями ранее на первой надпойменной террасе р. Северский Донец [15], вынудило жителей города искать другой, более дренированный и сухой участок для ее строительства. Перенос Белгорода на новое место был осуществлен в 1650 г. [16]. Несколько позднее в регионе стали происходить оползни, один из которых в 1666 г. разрушил крепостные стены г. Путивля [17]. Аналоги указанных процессов и их последовательность (сначала заболачивание надпойменных террас рек в конце 1980 -х годов, затем активизация оползневых процессов в 1990-2000-х годах (один из оползней весной 2000 г. разрушил часть жилого сектора в пос. Дубовое Белгородского района) наводят на мысль об идентичности фазовых проявлений внутривековой климатической цикличности (прохладно-влажных фаз циклогенеза в циклах Брикнера), наблюдавшихся в середине XVII и в конце XX вв.

Рассматривая длительные процессы в современном межледниковом тренде почвенного покрова юга Среднерусской возвышенности нами была обоснована разновозрастность возникновения зональных типов лесостепного почвообразования - черноземного и серо-лесного. При рассмотрении короткопериодической климатической цикличности (внутривековой природы) также можно выделить явления с разными характерными временами развития. На примере смен явлений, наблюдавшихся в последнюю прохладно-влажную фазу внутривекового изменения климата, нами предлагается следующая схема последовательности их возникновения на территории лесостепи Среднерусской возвышенности: 1980 г. достижение минимума температур вегетационного периода (май-сентябрь) в сглаженном многолетнем ряду изменений (см. рис. 3в); 1985 г. - появление литогенных мочаров на склоновом типе местности, маркируемых пятнами влаголюбивой растительности, начало заболачивания депрессий на первых надпойменных террасах рек; 1990 г. - достижение максимума атмосферных осадков, выпадающих в вегетационный период, начало четко обозначившегося тренда роста температур вегетационного периода в сглаженных многолетних рядах изменений (см. рис. Зв), продолжение формирования мочаров и интенсивного заболачивания на первых надпойменных террасах рек; 1995 г. - достижение минимальной глубины грунтовых вод на слабо дренируемых водоразделах Среднерусской лесостепи (см. рис. 4), максимальное проявление заболачивания и мочаризации ландшафтов; 1997 г. - начало оползнеобразования, обусловленного затяжными дождями в летний период и чередованием периодов с осадками и оттепелями в зимний период, исчезновение устойчивого снежного покрова зимой; 2000 г. - про- должение оползнеобразования, четко обозначившиеся тренды снижения количеств атмосферных осадков (см. рис. 3в) и понижения уровня грунтовых вод (см. рис. 4) в сглаженных многолетних рядах изменений данных показателей; 2010 г. сохранение трендового роста температур, снижения количеств атмосферных осадков, понижения уровня грунтовых вод на водоразделах, уменьшение площади болот на первых надпойменных террасах рек, затухание оползнеобразования, начало восстановления устойчивого снежного покрова в зимний период.

В соответствии с предложенной выше схемой смен во времени природных явлений, многие из которых относятся к категории опасных, и с учетом многолетнего хода метеорологических элементов (см. рис. За-3в), можно предположить, что максимальные проявления заболачивания, мочаризации, оползнеобразования, частых оттепелей зимой пришлись на переходный этап от прохладно-влажной к тепло-сухой фазам внутривекового климатического цикла. Логично предположить, что ожидаемый через 10-15 лет переход из тепло-сухой к прохладно-влажной фазе внутривекового цикла климата не будет сопровождаться указанными выше явлениями, так как тепло-сухая фаза должна характеризоваться относительно засушливым климатом без ведущей роли грунтовых вод в процессах ландшафтообразования в лесостепи.

\section{ВЫВОДЫ}

1. В длительных и коротких циклах развития почв и других компонентов природной среды юга Среднерусской возвышенности выявлены разные характерные времена их развития.

2. Черноземы как зональный тип почвообразования в лесостепи древнее второго зонального типа - серых лесных почв, образование которых на водоразделах связывается с эволюционными перестройками черноземов, оказавшихся под лесами в результате позднеголоценового надвигания лесов на степи.

3. На основании анализа 127-летнего ряда инструментальных метеонаблюдений на реперной станции Богородицкое-Фенино обосновано существование внутривековой цикличности климата с чередованием прохладно-влажных и тепло-сухих фаз в течение вегетационных периодов (май-сентябрь). В период с 1890 по 2017 г. обнаружены две парные смены указанных фаз со средней продолжительностью в 32 года. Квази-30-летние фазы внутривековых изменений климата соответствуют циклам Брикнера.

4. Последний из наблюдавшихся переход из прохладно-влажной к тепло-сухой фазе внутривекового изменения климата произошел в 1980- 
1990-е годы. Этот переход первоначально обозначился сменой трендов температурного режима вегетационного периода (начиная с 1980 г.), а затем - трендов выпадения осадков вегетационного периода (с 1990 г.). Он сопровождался неблагоприятными природными явлениями - подтоплением и заболачиванием надпойменных террас рек, образованием мочаров на склонах, оползнеобразованием, отсутствием устойчивого снежного покрова зимой. Развитие каждого из перечисленных явлений характеризовалось разновременностью возникновения и имело свои характерные времена.

5. Частным выводом, вытекающим из результатов анализа, является палеогеоморфологическое объяснение образования округлых или овальных контуров мочаров на склонах речных долин и балок, характерных для лесостепи Среднерусской возвышенности. Пятна мочаров с гидрофитной растительностью маркируют выклинивающиеся к поверхности современных склонов погребенные палеоложбины, которые заполнены относительно рыхлыми позднеплейстоценовыми склоновыми отложениями. В прохладно-влажные фазы внутривековых гелиоклиматических циклов геологические породы, которыми заполнены палеоложбины, насыщаются почвенными водами, которые затем выходят на поверхность в местах выклинивания к поверхности современных склонов указанных палеоложбин.

\section{ФИНАНСИРОВАНИЕ}

Работа выполнена при финансовой поддержке грантов РНФ, проект № 14-17-00171 (исследование реакции природной среды на внутривековые изменения климата), и РФФИ, проект № 19-29-05012 (изучение современного межледникового тренда климатического развития почв), а также темы госзадания № 01482019-0007 (подходы к оценке физико-географических, гидрологических и биотических изменений).

\section{FUNDING}

The study was financially supported by the Russian Science Foundation, project no. 14-17-00171 (analysis of environments responses to intra-centennial climate changes), and by the Russian Foundation for Basic Research, project no. 19-29-05012 (study of the modern interglacial trend of soils climatic development), as well as within the framework of the state-ordered research theme no. 0148-2019-0007 (approaches to assessing physical-geographical, hydrological, and biotic changes).

\section{СПИСОК ЛИТЕРАТУРЫ}

1. Александровский А.Л., Александровская Е.И. Эволюция почв и географическая среда. М.: Наука, 2005. $223 \mathrm{c}$.
2. Берг Л.С. Климат и жизнь. М.: Огиз - Географгиз, $1947.356 \mathrm{c}$.

3. Возраст и эволюция черноземов / под ред. Н.Я. Марголиной, А.Л. Александровского, Б.А. Ильичева и др. М.: Наука, 1988. 144 с.

4. Геннадиев А.Н. Почвы и время: модели развития. М.: Изд-во Моск. ун-та, 1990. 229 с.

5. Добровольский Г.В., Никитин Е.Д. Экологические функции почв. М.: Изд-во Моск. ун-та, 1986. 136 с.

6. Дьяконов К.Н., Ретеюм А.Ю. Астрогеография природных аномалий // Изв. РАН. Сер. геогр. 2016. № 6. С. $176-183$. https://doi.org/10.15356/0373-2444-2016-6-108-115

7. Еременко Е.А., Панин А.В. Происхождение ложбинной сети в центральных и южных районах Восточно-Европейской равнины // Вест. Моск. унта. Сер. 5. География. 2011. № 3. С. 59-66.

8. Зайдельман Ф.Р., Тюльпанов В.И., Ангелов Е.Н., Давыдов А.И. Почвы мочарных ландшафтов - формирование, агроэкология и мелиорация. М.: Издво Моск. ун-та, 1998. 160 с.

9. Иванов И.В. Эволюция почв степной зоны в голоцене. М.: Наука, 1992. 143 с.

10. Калесник С.В. Общие географические закономерности Земли. М.: Мысль, 1970. 283 с.

11. Кинд Н.В. Палеоклиматы и природная среда голоцена / История биогеоценозов СССР в голоцене. М.: Наука, 1976. С. 5-14.

12. Кислов А.В. Основы теории палеоклиматов плейстоцена и голоцена / Глобальные изменения природной среды. М.: Научный мир, 2000. С. 15-61.

13. Клименко Л.В. Колебания температуры воздуха на южной половине Европейской территории СССР в 1891-I990 гг. // Вестн. Моск. ун-та. Сер. 5. География. 1992. № 1. С. 25-30.

14. Максимов A.A. Природные циклы (причины повторяемости экологических процессов). Л.: Наука, 1989. $236 \mathrm{c}$.

15. РГАДА. Фонд 210. Столбцы Белгородского стола. Ед. хр. 224 (1), 1648. Л. 91.

16. РГАДА. Фонд 210. Столбцы Белгородского стола. Ед. хр. 914, 1650. Л. 232.

17. РГАДА. Фонд 210. Столбцы Белгородского стола. Ед. хр. 576, 1666. Л. 325.

18. Овечкин С.В., Исаев В.А. Периодическое дополнительное почвенно-грунтовое увлажнение как фактор эволюции почвенного покрова // Вопросы гидрологии в плодородии почв. М., 1985. С. 56-65.

19. Полупан Н.И. Эволюция почвенного покрова Украины под влиянием изменений природных условий и антропогенных воздействий: Тез. Докл. VIII Всесоюз. съезда почвоведов. Новосибирск, 1989. $66 \mathrm{c.}$

20. Полупан Н.И., Нестеренко А.Ф., Яровенко Е.В. Мочары и мочаристые почвы, их типология, пути улучшения и рационального использования: Тез. докл. 1-го Делегатского съезда почвоведов и агрохимиков Украинской ССР 8-11 июня 1982 г. Почвоведение. Харьков, 1982.75 с.

21. Савин И.Ю. Дешифрирование почвенного покрова лесостепи Центрально-Черноземного района по среднемасштабным космическим снимкам: Дис. .... канд. геогр. наук. М., 1990. 300 с.

22. Соловьев И.Н. К вопросу о современной эволюции почвенного покрова Черноземной зоны ЕТС / Антропогенная и естественная эволюция почв и поч- 
венного покрова: Тезисы Всесоюзного совещания (10-12 января 1989 г., М.-Пущино), 1989. С. 257-259.

23. Соколов И.А., Таргульян В.О. Взаимодействие почвы и среды: почва-память и почва-момент // Изучение и освоение природной среды. М., 1976. C. $150-164$.

24. Хитров Н.Б., Чевердин Ю.И. Почвы Каменной степи: Путеводитель научных полевых экскурсий VII съезда Общества почвоведов им. В.В. Докучаева и Всероссийской с зарубежным участием научной конференции "Почвоведение - продовольственной и экологической безопасности страны” (Белгород, 15-22 августа 2016 г.) / под ред. Ю.Г. Чендева. М.-Белгород: ИД “Белгород" НИу "БелГУ", 2016. С. 55-80.

25. Чендев Ю.Г. Естественная эволюция почв Центральной лесостепи в голоцене. Белгород: Изд-во БелГУ, 2004. 199 с.

26. Чендев Ю.Г. Эволюция лесостепных почв Среднерусской возвышенности в голоцене. М.: ГЕОС, 2008. $212 \mathrm{c}$.

27. Чендев Ю.Г. Медленные и быстрые реакции палеопочв на климатические изменения в голоцене / Палеопочвы, палеоэкология, палеоэкономика:
Материалы Всероссийской междисциплинарной научной конференции с международным участием. Пущино: Товарищество научных изданий KMK, 2017. C. 200-215.

28. Чендев Ю.Г., Лупо Э.Р., Лебедева М.Г., Борбукова Д.А. Региональные особенности климатической эволюции почв южной части Восточной Европы во второй половине голоцена // Почвоведение. 2015 T. 48. № 12. С. 1279-1291.

29. Чендев Ю.Г., Петин А.Н., Березуцкий В.Д., Долгих А.В., Белеваниев В.Г., Дудин Д.И. Голоценовые сигналы гумидизации климата в профилях разновозрастных черноземов центра Восточной Европы // Изв. ВУЗов, Северо-Кавказский регион. Естеств. науки. 2016. № 3. С. 100-109.

30. Чендев Ю.Г., Александровский А.Л., Хохлова О.С., Дергачева М.И., Петин А.Н., Голотвин А.Н., Сарапулкин В.А., Земцов Г.Л., Уваркин С.В. Эволюция лесного почвообразования на юге лесостепи Среднерусской возвышенности в позднем голоцене // Почвоведение. 2017. Т. 50. № 1. С. 1-13.

31. Jenny $H$. Factors of soil formation: a system of quantitative pedology. NY: McGraw-Hill, 1941. 281 p.

\title{
The Reaction of Soils and Natural Environment to Climate Changes of Different Periodicity in the South of Central Russian Upland
}

\author{
Yu. G. Chendev', \#, A. A. Tishkov', , , I. Yu. Savin ${ }^{3}$, M. G. Lebedeva', and A. B. Solovyov ${ }^{1}$ \\ ${ }^{1}$ Belgorod State National Research University, Institute of Earth Sciences, Belgorod, Russia \\ ${ }^{2}$ Institute of Geography, Russian Academy of Sciences, Moscow, Russia \\ ${ }^{3}$ Dokuchaev Soil Science Institute, Moscow, Russia \\ \#e-mail: sciences@mail.ru
}

\begin{abstract}
The responses of the natural environment components to climate change of different periodicity in the South of the Central Russian Upland were studied. The modern interglacial period in the climatic cycle of the "glacial-interglacial" epochs is considered as the reflection of the Holocene self-development of the upper humus part of the chernozems' profile. Less long period of self-development of zonal soils of the forest-steppe is substantiated for the profiles of automorphic gray forest soils of the region. These soils formed from chernozems due to the late Holocene cooling and the forests invasion on the steppes caused by it. The changes of natural environment components (soils, ground waters, swamp ecosystems) in heat-dry and cool-wet phases of intra-centennial climate changes (Brickner cycles) are compared. These changes were revealed based on the analysis of 127-year series of meteorological observations at the reference climatic station Bogoroditskoe-Fenino. The conceptual scheme of cyclical phenomena (increase of groundwater level, flooding, bogging, appearance of hydromorphic properties in soils, etc.) in connection with the intra-century climatic variability is proposed. The scheme's important methodological principle is the different age and different characteristic times of development of processes and phenomena forming the study area geosystems under the climate change influence.
\end{abstract}

Keywords: climate change, climatic cycles, Central Russian Upland, forest-steppe, soils, ground water

\section{REFERENCES}

1. Aleksandrovskii A.L., Aleksandrovskaya E.I. Evolutsiya pochv i geograficheskaya sreda [Evolution of Soil and Geographical Environment]. Moscow: Nauka Publ., 2005. 223 p.

2. Berg L.S. Klimat i zhizn' [Climate and Life]. Moscow: Ogiz-Geografgiz Publ., 1947. 356 p.

3. Vozrast i evolutsiya chernozemov [Age and Evolution of Chernozems]. Margolina N.Ya., Aleksandrovskii A.L.,
Il'ichev B.A. et al., Eds. Moscow: Nauka Publ., 1988. $144 \mathrm{p}$.

4. Gennadiev A.N. Pochvy i vremya: modeli razvitiya [Soils and Time: Models of Development]. Moscow: Mosk. Gos. Univ., 1990. 229 p.

5. Dobrovolskii G.V., Nikitin E.D. Ekologicheskie funktsii pochv [Ecological Functions of Soils]. Moscow: Mosk. Gos. Univ., 1986. 136 p.

6. Dyakonov K.N., Reteyum A.Yu. Astrogeography of natural anomalies. Izv. Akad. Nauk, Ser. Geogr., 2016, 
no. 6, pp. 176-183. (In Russ.). doi: 10.15356/03732444-2016-6-108-115

7. Eremenko E.A., Panin A.V. The origin of the hollow network in the central and southern regions of the East European Plain. Vestn. Mosk. Univ., Ser. 5: Geogr., 2011, no. 3, pp. 59-66. (In Russ.).

8. Zaidelman F.R., Tyul'panov V.I., Angelov E.N., Davydov A.I. Pochvy mocharnykh landshaftov - formirovanie, agroekologiya i melioratsiya [Soils of the Mochar Landscapes - Formation, Agroecology and Melioration]. Moscow: Mosk. Gos. Univ., 1998. 160 p.

9. Ivanov I.V. Evolyutsiya pochv stepnoi zony v golotsene [Evolution of Soils in the Steppe Zone in the Holocene]. Moscow: Nauka Publ., 1992. 143 p.

10. Kalesnik S.V. Obshchie geograficheskie zakonomernosti Zemli [General Geographical Patterns of the Earth]. Moscow: Mysl' Publ., 1970. 283 p.

11. Kind N.V. Paleoclimates and the natural environment of the Holocene. In Istoriya biogeotsenozov SSSR v golotsene [The History of Biogeocenoses of the USSR in the Holocene]. Moscow: Nauka Publ., 1976, pp. 5-14. (In Russ.).

12. Kislov A.V. Fundamentals of the theory of paleoclimates Pleistocene and Holocene. In Global'nye izmeneniya prirodnoi sredy [Global Changes in the Natural Environment]. Moscow: Nauka Publ., 2000, pp. 1561. (In Russ.).

13. Klimenko L.V. Fluctuations in air temperature in the southern half of the European territory of the USSR in 1891-1990. Vestn. Mosk. Univ., Ser. 5: Geogr., 1992, no. 1, pp. 25-30. (In Russ.).

14. Maksimov A.A. Prirodnye tsikly (prichiny povtoryaemosti ekologicheskikh protsessov) [Natural Cycles (Causes of Recurrence of Ecological Processes)]. Leningrad: Nauka Publ., 1989. 236 p.

15. Columns of the Belgorod Table, 1648. Russian State Archives of Ancient Documents (RGADA), Moscow, fund 210, unit 224 (1). 91 p. (In Russ.).

16. Columns of the Belgorod Table, 1650. Russian State Archives of Ancient Documents (RGADA), Moscow, fund 210, unit 914. 232 p. (In Russ.).

17. Columns of the Belgorod Table, 1666. Russian State Archives of Ancient Documents (RGADA), Moscow, fund 210, unit 576. 325 p. (In Russ.).

18. Ovechkin S.V., Isaev V.A. Periodic additional soil-soil moistening as a factor in the evolution of the soil cover. In Voprosy gidrologii v plodorodii pochv [Questions of Hydrology in Soil Fertility]. M., 1985, pp. 56-65. (In Russ.).

19. Polupan N.I. Evolution of the soil cover of Ukraine under the influence of changes in natural conditions and anthropogenic impacts. In Tezisy dokladov VIII Vsesoyuznogo s"ezda pochvovedov [Abstracts of the VIII All-Union Congress of Soil Scientists]. Novosibirsk, 1989. 66 p. (In Russ.).

20. Polupan N.I., Nesterenko A.F., Yarovenko E.V. Mochars and mochar soils, their typology, ways of improvement and rational use. In Tezisy dokladov 1-go Delegatskogo s"ezda pochvovedov $i$ agrokhimikov Ukrainskoi SSR 8-10 iyunya 1982 g. Pochvovedenie [Abstracts of the 1st Delegate Congress of Soil Scientists and Agrochemists of the Ukrainian SSR, 8-11 June 1982. Soil Science]. Kharkiv, 1982, 75 p. (In Russ.).

21. Savin I.Yu. Mapping the soil cover of the forest-steppe of the Central Chernozem region with medium-scale satellite imagery. Cand. Sci. (Geogr.) Dissertation. Moscow: Dokuchaev Soil Sci. Inst., 1990. 300 p.

22. Solov'ev I.N. To the question of the modern evolution of the soil cover of the Chernozem zone of the European part of Russia. In Antropogennaya i estestvennaya evolyutsiya pochv i pochvennogo pokrova: Tezisy Vsesoyuznogo soveshaniya 10-12 yanvarya $1989 \mathrm{~g}$. [Anthropogenic and Natural Evolution of Soils and Soil Cover: Theses of the All-Union Conference, 10-12 January 1989]. Moscow, Pushchino, 1989, pp. 257-259. (In Russ.).

23. Sokolov I.A., Targulyan V.O. Interaction of soil and environment: soil-memory and soil-moment. In Izuchenie i osvoenie prirodnoi sredy [Study and Development of the Natural Environment]. M., 1976, pp. 150-164. (In Russ.).

24. Khitrov N.B., Cheverdin Yu.I. Soil of the Kamennaya steppe. In Putevoditel' nauchnykh polevykh ekskursii VII s'ezda Obshestva pochvovedov im. V.V. Dokuchaev i Vseross. s mezhd. uchastiem konf. "Pochvovedenie - prodovol'stvennoi $i$ ekologicheskoi bezopasnosti strany" [Guide to the Scientific Field Excursions of the VII Congress of the Dokuchaev Society of Soil Scientists and All-Russian Sci. Conf. "Soil Science - Food and Ecological Security of the Country" (Belgorod, August 15-22, 2016)]. Chendev Yu.G., Ed. Moscow-Belgorod: Belgorod. Gos. Univ., 2016, pp. 55-80. (In Russ.).

25. Chendev Yu.G. Estestvennaya evolutsiya pochv Tsentral'noi lesostepi v golotsene [Natural Evolution of Soils in the Central Forest-Steppe in the Holocene]. Belgorod: Belgorod. Gos. Univ., 2004. 199 p.

26. Chendev Yu.G. Evolutsiya lesostepnykh pochv Srednerusskoi vozvyshennosti v golotsene [Evolution of Forest-steppe Soils of the Central Russian Upland in the Holocene]. Moscow: GEOS Publ., 2008. 212 p.

27. Chendev Yu.G. Slow and rapid paleocholic reactions to climatic changes in the Holocene. In Paleopochvy, paleoekologiya, paleoekonomika [Paleosoils, Paleoecology, Paleoeconomics]. Pushchino: KMK Publ., 2017, pp. 200-215. (In Russ.).

28. Chendev Yu.G., Lupo E.R., Lebedeva M.G., Borbukova D.A. Regional specificity of the climatic evolution of soils in the southern part of eastern Europe in the second half of the Holocene. Eurasian Soil Sci., 2015, vol. 48, no. 12, pp. 1279-1291.

29. Chendev Yu.G., Petin A.N., Berezutskii V.D, Dolgikh A.V., Belevantsev V.G., Dudin D.I. Holocene signals of climatic humidity in chernozem soils of different historical periods within center of Eastern Europe. Izv. Vuzov. Severo-Kavkazskii Reg., Ser. Estestv. Nauki, 2016, no. 3, pp. 100-109. (In Russ.).

30. Chendev Yu.G., Aleksandrovskii A.L., Khokhlova O.S. Dergacheva M.I., Petin A.N., Golotvin A.N., Sarapulkin V.A. Zemtsov G.L., Uvarkin S.V. Evolution of forest pedogenesis in the south of the forest-steppe of the Central Russian Upland in the Late Holocene. Eurasian Soil Sci., 2017, vol. 50, no. 1, pp. 1-13.

31. Jenny H. Factors of Soil Formation: A System of Quantitative Pedology. N.Y.: McGraw-Hill, 1941. 281 p. 